\title{
A Novel N18TG2 $\times$ Mesencephalon Cell Hybrid Expresses Properties That Suggest a Dopaminergic Cell Line of Substantia Nigra Origin
}

\author{
Garrett D. Crawford, Jr.,' Wei-Dong Le,' R. Glenn Smith,' Wen-Jei Xie, ${ }^{1}$ Enrico Stefani,, and Stanley H. Appel' \\ Departments of ${ }^{1}$ Neurology and ${ }^{2}$ Molecular Physiology and Biophysics, Baylor College of Medicine, Houston, Texas 77030
}

\begin{abstract}
A dopaminergic neuroblastoma was derived using somatic cell fusion of rat embryonic mesencephalon cells and the murine neuroblastoma-glioma cell line N18TG2. The resulting interspecies hybrid, named MES23.5, has retained a stable phenotype and karyotype for a continuous culture period of 1 year.

The hybrid exhibits several properties that suggest that the parent primary neurons originated in the substantia nigra. The cell line contains tyrosine hydroxylase, which is identifiable both by biochemical and immunological methods and synthesizes dopamine, but no other catecholamine. Additionally, the cell line expresses apparent voltage-gated $\mathrm{CA}^{2+}$ channels as measured by high-affinity $\omega$-conotoxin binding. The MES23.5 $\omega$-conotoxin receptors are of similar affinity class to those found in adult rat mesencephalon. No dihydropyridine receptors, as measured by PN200-100 ligand binding, are present. None of these properties are found in the N18TG2 parent. At least three neuronal features, namely, tyrosine hydroxylase, dopamine synthesis, and $\omega$-conotoxin receptor expression, are quantitatively elevated after sustained treatment with cAMP analogs. The cell line expresses a complex range of neural properties found in the dopaminergic neurons of the substantia nigra, and may therefore be useful elucidating further details of their cell biology.
\end{abstract}

Cultures of primary neural cells and neuroblastoma cell lines are widely employed to discern aspects of neuronal function. Primary cultures are inherently heterogeneous, containing many cell types at different stages of development. Frequently the cell type of interest is a minor component of the total. Thus, while these cultures have the potential to reproduce conditions found in whole tissue, they are difficult to control. In contrast, tumor cell lines are homogeneous and easily cultured cell populations, allowing individual characteristics to be magnified. However, these cells do not typically exhibit the well-differentiated properties of single neurons. For instance, several neurotransmitter phenotypes are often expressed in a single cloned tumor line (Ross et al., 1981). Additionally, cloned tumor lines usually express only a limited set of the characteristics (Nirenberg et al., 1983) that phenotypically define individual neuron classes.

\footnotetext{
Received Dec. 12, 1991; revised Mar. 23, 1992; accepted Apr. 3, 1992.

This work was supported by the Cullen Foundation. The parent neuroblastoma, N18TG2, was obtained as a gift from Dr. Marshall Nirenberg, National Heart Lung Institute, Bethesda, MD.

Correspondence should be addressed to Stanley H. Appel, M.D., Department of Neurology, Baylor College of Medicine, 6501 Fannin, \#NB302, Houston, TX 77030 .

Copyright (C) 1992 Society for Neuroscience $0270-6474 / 92 / 123392-07 \$ 05.00 / 0$
}

Somatic cell fusion of tumor cell lines with primary cell lines partially obviates this problem by production of new cell lines expressing highly differentiated characteristics. Often the properties of such cells reflect those of normal tissue more closely than do neuroblastoma, especially in the fidelity of neurotransmitter expression (Lendahl and McKay, 1990). Many laboratories are employing this technology to develop hybrid cell lines that express complex properties of neurons, among them the adrenergic cells of the superior cervical ganglion (Greene et al., 1975) and the cholinergic neurons found in rodent septal nucleus (Hammond et al., 1986, 1990) and ventral spinal cord (Cashman, 1991). This report describes the isolation and characterization of a dopaminergic cell line derived from the rat mesencephalon.

The cells in the basal ganglia play an important role in the control of motor function and less clearly defined roles in cortical and emotional functions (Burns et al., 1985). Because of the biochemical complexity of the tissue, and its diverse and extensive synaptic connections to other regions, it is difficult to relate changes reliably in Parkinsonian tissue with changes in specific cells. However, the progressive degeneration of the dopaminergic neurons in the substantia nigra is accepted as a definitive hallmark of Parkinson's disease (Bernheimer et al., 1973; Penney and Young, 1983). Many theories are proposed to account for this remarkable degenerative process. The deleterious effects of 1-methyl-4-phenyl-1,2,3,6-tetrahydropyridine metabolites on dopaminergic cells (Burns et al., 1983, 1985) encourages speculation that toxins (Spencer et al., 1991) or other environmental factors may promote degeneration. Changes in mitochondrial metabolism in the affected neurons (Leehey and Boyson, 1991) appear to weaken the dopaminergic neuron's capacity to survive oxidative stress. A recent epidemiological study suggests that development of Parkinson's disease may correlate with earlier closed head trauma (Stern et al., 1991). The physical damage sustained may release neural proteins into the extracellular medium and/or activate local immune traffic. This may explain the presence of dopaminergic cell-reactive antibodies in cerebrospinal fluid and sera of Parkinson's patients (Dahlstrom et al., 1990; Carvey et al., 1991) and suggests an autoimmune component. The hybrid dopaminergic cell line MES23.5 may be useful in the relative assessment of these hypotheses.

\section{Materials and Methods}

Sato's N1 medium (Bottenstein and Sato, 1979) was formulated with powdered Dulbecco's modified Eagle's medium/F12, human transferrin, insulin, progesterone, pyruvic acid, sodium selenite, gentamicin, and HEPES using high-resistivity water with tissue culture grade reagents from Sigma (St. Louis, MO). Other tissue culture-grade reagents 
included Hybrimax fetal bovine serum (FBS), newborn calf serum, polyethylene glycol (MW, 1300-1600), phytohemagglutinin A (PA), DNase I. trypsin, and poly-L-ornithine also from Sigma. Substrates for radiometric enzyme assays, $\mathrm{L}$-carboxyl- ${ }^{14} \mathrm{C}$-tyrosine (specific activity, 50 $60 \mathrm{mCi} / \mathrm{mmol}$ ) and ${ }^{3} \mathrm{H}$-acetyl coenzyme $\mathrm{A}$ (specific activity, $2-10 \mathrm{Ci} /$ $\mathrm{mmol}$ ), and for ligand binding assays, ${ }^{3} \mathrm{H}-\mathrm{PN} 200-100$ (specific activity, $72.3 \mathrm{Ci} / \mathrm{mmol}$ ) and ${ }^{125} \mathbf{I}-\omega$-conotoxin GIVA (specific activity, $2000 \mathrm{Ci} /$ $\mathrm{mmol}$ ), were purchased from New England Nuclear(Boston, MA). Other cofactors and buffer components for these assays were standard reagent grade. Gamma globulin-free bovine serum albumin (BSA) used as carrier for $\omega$-conotoxin binding assays was purchased from Sigma. Nifedipine was purchased from Calbiochem (La Jolla, CA), and unlabeled $\omega$-conotoxin, from Peptide Institute, Inc. (Osaka, Japan). Polyclonal antiserum reactive with tyrosine hydroxylase (TH) was purchased from Chemicon (Temeculah, CA); alkaline phosphatase-conjugated anti-rabbit IgG and the Protoblot BCIP detection reagent for immunoblotting were purchased from Fisher (Dallas, TX). Imobilon electroblot membrane was purchased from Milipore (Bedford, MA).

Cell fusion and selection. The murine parent tumor, N18TG2 (Nelson et al., 1969), was maintained in log phase growth prior to fusion. The mesencephalon from embryonic day 16 rat embryos, dissected to minimize the content of other catecholaminergic cell groups (Konig et al., 1989), was mechanically dissociated by trituration in complete Hank's balanced salts (HBSS) containing $3 \mathrm{mg} / \mathrm{ml}$ DNase I. After $5 \mathrm{~min}$ at room temperature, the dissociated cells were collected by centrifugation ( 300 $\times g, 5 \mathrm{~min}$ ). The N18TG2 cells were harvested and both tumor and primary cells were washed three times in HBSS to minimize free protein. All washes and other treatments were carried out in HBSS.

The mesencephalon cells were again triturated to ensure uniform dispersion and incubated with phytohemagglutinin A (PA) (Hammond et al., 1986, 1990). PA-coated primary cells were allowed to agglutinate with washed N18TG2 cells at a ratio of $10: 1$ and were then centrifuged. The cell pellet was gently resuspended in $50 \mu 1$ HBSS and fusion accomplished by addition of $1 \mathrm{ml} 50 \%$ polyethylene glycol over a period of $1 \mathrm{~min}$ at $37^{\circ} \mathrm{C}$. The fusion mixture was then slowly diluted with 5 ml HBSS over a $5 \mathrm{~min}$ period with gentle agitation. The cells were collected by centrifugation and distributed into five-microwell plates with $0.1 \mathrm{ml} /$ well Sato's N1 medium (Bottenstein and Sato, 1979) containing $10 \%$ FBS. The fusion mixture was cultured overnight, after which authentic hybrids were selected by addition of an equal volume $2 \times$ HAT in the same medium (Littlefield, 1964). HAT selection was continued for $10 \mathrm{~d}$. All wells were fed twice weekly by $50 \%$ medium replacement for 3 weeks.

Selection of tyrosine hydroxylase-positive colonies. When robust colonies became apparent, each colony was subdivided fivefold by trypsin treatment. One culture was retained for expansion; the others were utilized for tyrosine hydroxylase (TH) activity determinations by a technique recently described (Bostwick and Le, 1991). The cells were cultured 4 additional days. One duplicate pair was supplemented with 1 mM dibutryl-cAMP throughout the culture period; the other duplicate pair was maintained in the basal Sato's medium. Two wells that contained robust TH activity were expanded, and clones were selected by limiting dilution. A single clone that responded to dibutryl-cAMP was examined in this study. This cell line was adapted to culture in $2 \%$ newborn calf serum in Sato's medium prior to this study.

Most experiments were performed on cells grown in large, low-density cultures in order to permit TH and catecholamine determinations on aliquots from the same culture. Every effort was made to ensure that cells growing in these conditions remained in log phase growth throughout the treatment period. Additional experiments were performed in microwells at high density. In these experiments, choline acetyltransferase was evaluated on sister microwell cultures using the modified Fonnum assay (Rand and Johnson, 1981) with ${ }^{3} \mathrm{H}$-acetyl-coenzyme $\mathrm{A}$ $(2980 \mu \mathrm{Ci} / \mathrm{mmol}$ specific activity).

Characterization of dopaminergic phenotype. Cells grown on poly-Lornithine-coated plastic to a maximum density of $2000 \mathrm{cells} / \mathrm{mm}^{2}$ in 1 $\mathrm{mM}$ dibutryl-cAMP for $6 \mathrm{~d}$ prior to harvesting. These cells were harvested by incubation in $2 \mathrm{mM}$ EDTA, $\mathrm{Ca}^{2+} / \mathrm{Mg}^{2+}$-free HBSS $1 \mathrm{hr}$ at $37^{\circ} \mathrm{C}$, and released from the plastic by gentle pipetting. After four washes in HBSS, the cells were generally $80-85 \%$ viable as assessed by trypan blue exclusion. Catecholamines were extracted from whole cell pellets containing $1 \times 10^{\circ}$ cells with $50 \mu 110 \%$ perchloric acid, clarified by centrifugation, and chromatographed by HPLC on Waters Radial-Pak cartridge packed with $C_{18}$ Resolve resin. The acid extract was applied isochratically and detected electrochemically according to published procedures (Morier and Rips, 1982). Catecholamines were identified by coelution with standards. Tyrosine hydroxylase and total protein were assessed in an aliquot of the same cells resuspended in PBS with $0.5 \%$ NP40.

Characterization of $\mathrm{Ca}^{2+}$ channel pharmacology. The presence of voltage-gated $\mathrm{Ca}^{2+}$ channels was evaluated using $\omega$-conotoxin (Marquez et al., 1988) and PN200-100 (Glossmann and Ferry, 1985) ligand binding, using washed whole cells grown in low-density cultures. Total $\omega$-conotoxin binding was assessed over a concentration range of $1-300 \mathrm{pM}$ using ${ }^{125} \mathrm{I}-\omega$-conotoxin $(2000 \mu \mathrm{Ci} / \mathrm{mmol}$ specific activity), similar to published procedures (Marquez et al., 1988). Binding reactions were carried out at room temperature with $5-10 \mu \mathrm{g}$ of protein $(25,000$ cells) in BSAcoated microwells. Nonspecific $\omega$-conotoxin binding was evaluated using samples pretreated $5 \mathrm{~min}$ with $5 \mu \mathrm{M}$ unlabeled $\omega$-conotoxin. Similarly, PN200-100 ligand binding was assessed over a concentration range of $0.1-10 \mathrm{nM}$ using ${ }^{3} \mathrm{H}-\mathrm{PN} 200-100(2840 \mu \mathrm{Ci} / \mathrm{mmol}$ specific activity), similar to published procedures (Glossmann and Ferry, 1985). Binding reactions were carried out at $10^{\circ} \mathrm{C}$ in the dark, with $25 \mu \mathrm{g}$ of protein $(125,000$ cells). Nonspecific binding was evaluated in the presence of $2 \mu \mathrm{M}$ nifedipine. Filter-retained ${ }^{125} \mathrm{I}-\omega$-conotoxin was measured by gamma counting and retained ${ }^{3} \mathrm{H}-\mathrm{PN} 200-100$ in a Liquifluor scintillation cocktail.

Immunoblot detection of tyrosine hydroxylase. Electroblots were prepared with cells harvested after $6 \mathrm{~d}$ of low-density culture in the presence or absence of $1 \mathrm{mM}$ dibutryl-cAMP. The washed cells were solubilized in $6 \%$ SDS and prepared for electrophoresis (Laemmli, 1970). Prior to electrophoresis, the solubilized preparation was clarified in a Beckman airfuge at $175,000 \times g$ for $1 \mathrm{hr}$ to remove DNA and insoluble matter. Extracts were electrophoresed in 10\% SDS polyacrylamide and electroeluted onto Imobilon (Towbin et al., 1979). Tyrosine hydroxylase was detected by incubating the blot with a 1:1000 dilution of rabbit anti- $\mathrm{TH}$, followed by a 1:1000 dilution of alkaline phosphatase-conjugated anti-rabbit IgG both in PBS with $0.05 \%$ Tween-20, for $2 \mathrm{hr}$ at room temperature. The Fisher Protoblot BCIP detection system was utilized for color development according to the manufacturer's specifications.

Karyotype analysis. Chromosome analyses were performed on cells after continuous culture for 4 and 12 months following the cloning by limiting dilution. Conventional Gimsa-stained chromosome spreads (Yoshida and Amano, 1965) were prepared from parent N18IG2 and MES23.5 cell lines and 15 profiles each were examined.

Quantitative protein assessment was performed by the bichinchonic acid method using BSA as a standard (Smith et al., 1985). Cell counts were performed in PBS-buffered $0.1 \%$ trypan blue using a hemocytometer.

\section{Results}

\section{Identification of adrenergic hybrids}

Subsequent to fusion, HAT selection was applied for $10 \mathrm{~d}$. During this time, a control culture of N18TG2 parent cells was completely killed. Four weeks after fusion, 23 robust colonies were screened for dibutryl-cAMP-inducible TH (Fig. 1). Other wells contained similar but slowly growing cells. Many of these slowly growing hybrids did not survive beyond 6 weeks and were not further assessed. Two colonies expressed high levels of TH. One colony (colony 23) appeared to contain cells in which TH was increased after exposure to dibutryl-cAMP. This cell line was cloned by limiting dilution. All derived lines that appeared by visual inspection to have grown from single cells were also TH positive. Clone 5 was expanded for these experiments, hence the name MES23.5.

\section{Karyotype analysis}

The murine parent N18TG2 contained highly characteristic, very large chromosomes, some of which were retained in the hybrid (Fig. 2). Karyotypic analysis of N18TG2 indicated a range of 59-120 chromosomes with a single modal number of $82(n=11)$. The first three chromosomes displayed in the top line of Figure $2 A$ were consistently found in every N18TG2 


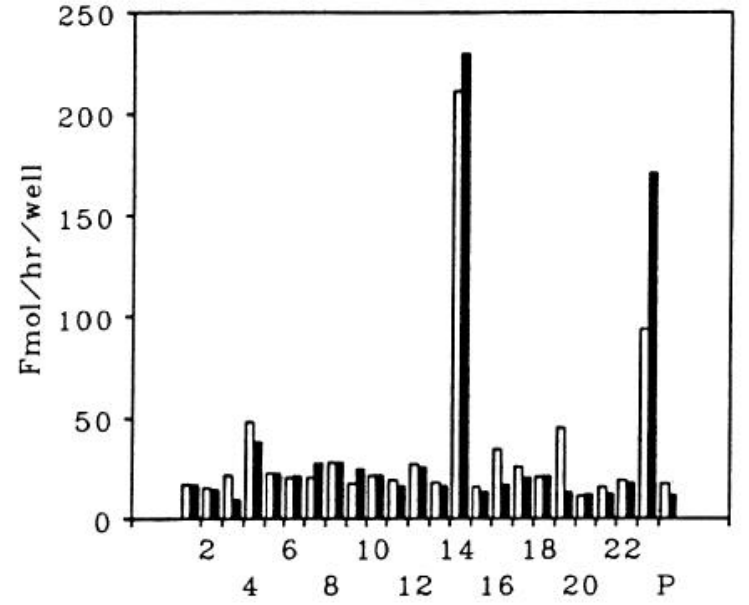

Figure 1. The mesencephalon hybrids were first screened for TH activity. Wells containing robust hybrids were subdivided and cultured for 4 days in either the absence $(\square)$ or presence $(\square)$ of $1 \mathrm{mM}$ dibutrylcAMP. TH was subsequently measured in each culture. Two cell lines expressed large amounts of activity, although several were significantly greater than the parental tumor $(P)$. One cell line, line 25 , contained a cAMP-inducible TH activity.

\section{$\zeta<\}<>\gg 11$

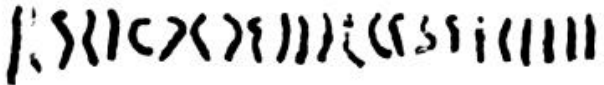

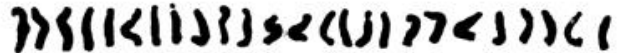

\section{! $1111100,111111 \ldots$} Xrsers88

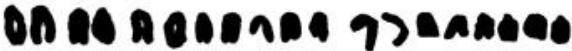

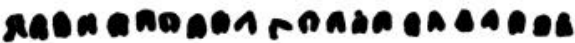

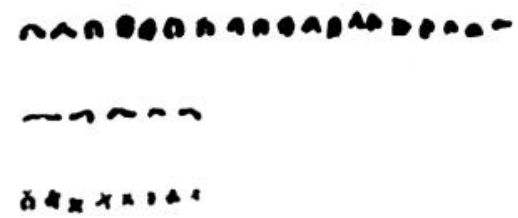

Figure 2. Chromosomal spreads were analyzed from the parental N18TG2 cell line and the MES23.5 mesencephalon hybrid. Chromosomal spreads from the parental N18TG2 cell line $(A)$ contain highly characteristic large chromosomes found in tumors. The first three chromosomes are markers for this cell line and were found in every spread. Chromosome spreads from the mesencephalon hybrid, MES23.5 (B), contained some very large chromosomes, but largely consisted of small, metacentric chromosomes very characteristic of rat diploid cells. The last eight chromosomes are acrocentric marker chromosomes for rat cell lines and were observed in every hybrid spread.

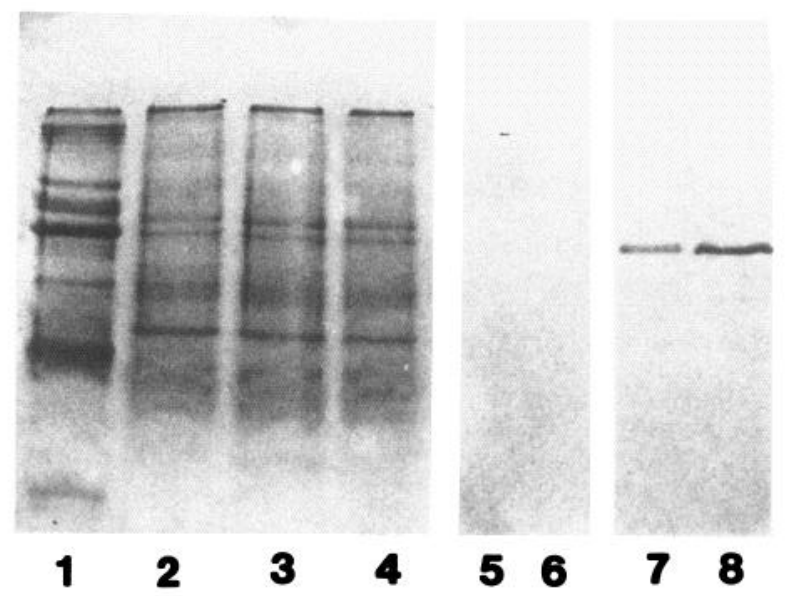

Figure 3. TH is detected by immunoblot in homogenates of the mesencephalon hybrid MES23.5 but not the parental cell line N18TG2. Lanes $1-4$ are Coomassie blue stained. Slot 1 , a molecular weight standard mixture of myosin, $\beta$-galactosidase, phosphorylase b, BSA, ovalbumin, and carbonic anhydrase. The molecular weight assignments are shown in the left margin. Slots 2-4 contain $20 \mu \mathrm{g}$ of untreated N18TG2, untreated MES23.5, and cAMP-treated MES23.5, respectively. Slots 58 are identical samples electroblotted and subsequently stained for TH. Only untreated and cAMP-treated MES23.5 cell homogenates show an immunoreactive band.

chromosome spread. Chromosome number in the mesencephalon hybrid MES23.5 varied from 74 to 108 with a single modal number of $87(n=13)$. Diploid rat cells have been shown contain small metacentric chromosomes and a few highly characteristic acrocentric chromosomes (Yoshida and Amano, 1965). The bulk of the mesencephalon hybrid chromosomes are small and metacentric, very similar in size and shape to those reported for rat cells. The hybrid also contains 6-12 small acrocentric chromosomes shown in the last line of Figure $2 B$ that are very similar to those characteristic of rat diploid cells. Similar karyotypic analyses, both quantitatively and qualitatively, were obtained after 4 months and 12 months in continuous culture, indicating an unusual degree of stability.

\section{Identification of $\mathrm{TH}$}

TH epitopes were detected exclusively in untreated and dibutryl-cAMP-treated cultures as shown by immunoblot (Fig. 3) but not in N18TG2 cells, regardless of culture conditions. A single molecular weight species of $61,300 \mathrm{Da}$ has been purified from rat striatum (Richtand et al., 1985), and a single species of identical molecular weight was detected in these cells by a polyclonal monospecific rabbit antiserum. An amount of protein from untreated cells was chosen for electrophoresis that resulted in light immunostaining. Similar amounts of protein from the treated cultures exhibited noticeably stronger staining.

\section{Cyclic nucleotide regulation of $T H$}

The cell division rate was profoundly depressed over the course of the dibutryl-cAMP treatment in a dose-dependent manner (data not shown). In basal culture conditions, the cells divided every $8 \mathrm{hr}$. After $6 \mathrm{~d}$ of treatments, the doubling time increased to $25 \mathrm{hr}$. All quantitative measurements were normalized to cell protein to allow comparisons with other cell studies; however, the elevation of $\mathrm{TH}$ was equally prominent when calculated on a per cell basis. 


\begin{tabular}{llll}
\hline Table 1. Neurotransmitter systems & & \\
& $\begin{array}{l}\text { CAT } \\
\text { (fmol/hr/mg protein) }\end{array}$ & $\begin{array}{l}\text { TH (nmol/hr/mg } \\
\text { protein) }\end{array}$ & $\begin{array}{l}\text { DA (pmol/mg } \\
\text { protein) }\end{array}$ \\
\hline $\begin{array}{l}\text { I } \text { ow-density log phase cultures } \\
\text { Untreated MES23.5 }\end{array}$ & $0.109 \pm 0.017$ & $5.96 \pm 0.31$ & $224.9 \pm 10.1$ \\
cAMP MES23.5 & NA & $36.6 \pm 0.13$ & $541.0 \pm 4.2$ \\
Untreated N18TG2 & $0.115 \pm 0.021$ & $\mathrm{ND}$ & $\mathrm{ND}$ \\
cAMP N18TG2 & $\mathrm{NA}$ & $\mathrm{ND}$ & $\mathrm{ND}$ \\
$\begin{array}{l}\text { High-density microwell cultures } \\
\text { Untreated MES23.5 }\end{array}$ & $0.119 \pm 0.017$ & $34.6 \pm 0.31$ & \\
$\begin{array}{l}\text { cAMP MES23.5 } \\
\text { Untreated N18TG2 }\end{array}$ & $0.119 \pm 0.012$ & $113.0+0.13$ & \\
cAMP N18TG2 & $0.123 \pm 0.021$ & $\mathrm{ND}$ & \\
\hline
\end{tabular}

Both cell lines were grown continuously in log phase conditions to less than $50 \%$ confluence for low-density cultures. CAT, TH, and DA were assessed in tandem from the same freshly harvested washed cells whose viability was routinely greater than $80 \%$. The data shown are means \pm SD of three replicates of triplicate assays. Data are not only shown for dibutryl-cAMP treatments (cAMP). In high-density cultures, cells achieved maximal density. Cells in sister wells were counted and contained $80-85 \%$ trypan-excluding cells. The data shown are means \pm SD of triplicate wells. NA, not assessed; ND, lower than detectable limit.

Basal and dibutryl-cAMP-elevated levels of TH are shown in Table 1. Basal TH levels determined from washed cells grown at low density were threc- to sixfold lower than basal levels determined from cells grown in high-density microwell culture. A smaller difference (threefold) was found between dibutrylcAMP-treated cultures grown in low-density cultures and highdensity microwell cultures. Thus, an average 6.4-fold TH elevation on either a protein or a cellular basis was observed under low-cell-density culture conditions after the dibutryl-cAMP treatment (Table 1), while an average threefold TH elevation was observed in high-density microwell cultures.

The degree of elevation of $\mathrm{TH}$ activity was clearly dependent on dibutryl-cAMP concentration; maximal stimulation was observed at $1 \mathrm{mM}$ dibutryl-cAMP (Fig. 4). A similar TH elevation of fivefold was observed after similar treatment with $2 \mathrm{mM}$ 8-Br-cAMP. The concentration at which half-maximal stimu-

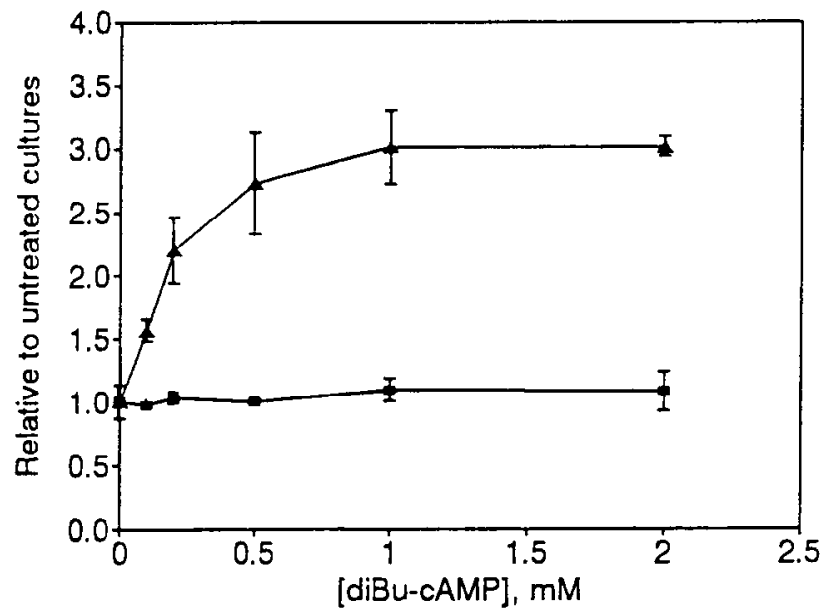

Figure 4. cAMP analogs elevate $\mathrm{TH}$ in the mesencephalon hybrid MES23.5, but do not induce an elevation of CAT activity. Individual microwells of the hybrid cells were grown at high density and exposed for $6 \mathrm{~d}$ to a range of $0-2 \mathrm{mM}$ dibutryl-cAMP as indicated. TH activity was measured in duplicate wells and cells were counted in duplicate sister cultures. TH activity under these conditions is elevated threefold relative to untreated cultures, while CAT activity remains unchanged. The concentration that yields half-maximal induction is $0.1 \mathrm{mM}$ dibutryl-cAMP. lation was achieved, $0.1 \mathrm{mM}$, and the treatment time needed to observe maximal TH elevation, $4 \mathrm{~d}$, was identical in both primary mesencephalon cultures and the hybrid cell line (data not shown). CAT, present at barely detectable levels in both the parent N18TG2 and the hybrid MES23.5, was not altered by this treatment. The CAT activity, although quite small, was bone fide; the small amount of ACh formed was completely hydrolyzed by subsequent treatment with excess $\mathrm{AChE}$ and its synthesis was inhibited by $1 \mathrm{mM}$ napthovinylpyridine. Similar levels of dibutryl-cAMP-insensitive CAT activity were also observed in N18TG2 cells.

The cellular content of TH in MES23.5 (Table 2) was similar to that expected in embryonic and adult ventral mesencephalon dopaminergic cells. The adult substantia nigra area has been reported to contain approximately 22,000 dopaminergic cells as assessed immunohistochemically with antisera specific for dopamine (DA) or TH (Bjorkland and Lindvall, 1984). However, the embryonic source area has been reported to contain an overproduction of up to eightfold in specific nerves immediately after the last birth date (Oppenheim, 1991). Although specific data for naturally occurring cell death for this region have not yet been reported, we assumed an overproduction of 2.5-fold for TH-containing cells, consistent with that found in other regions with extensive target fields (Purves, 1988). Specifically, the content of TH-positive cells in the embryonic mesencephalon was assumed to be 55,000. As shown, the TH

Table 2. TH content calculated per cell

\begin{tabular}{lcl} 
& $\begin{array}{l}\text { Untreated } \\
(\mathrm{fmol} / \mathrm{hr} / \mathrm{cell})\end{array}$ & $\begin{array}{l}\text { cAMP } \\
(\mathrm{fmol} / \mathrm{hr} / \mathrm{cell})\end{array}$ \\
\hline E16 mesencephalon & $1.34 \pm 0.003$ & - \\
Adult mesencephalon & $56.7 \pm 5.30$ & - \\
Low-density MES23.5 & $0.537 \pm 0.028$ & $3.30 \pm 0.012$ \\
High-density MES23.5 & $4.85 \pm 0.043$ & $15.8 \pm 0.018$
\end{tabular}

Embryonic day 16 (E16) mesencephalon contained adrenergic areas 8,9 and 10 . Adult mesencephalon was dissected to contain only areas 8 and 9. Whole homogenales were prepared, dispersed in detergent, and analyzed for TH activity. Calculations were performed assuming 55,000 dopaminergic cells in embryonic and 22,000 dopaminergic cells in adult tissue. 
Table 3. $\omega$-Conotoxin binding sites

\begin{tabular}{llcl} 
& $\begin{array}{l}K_{1} \\
\left.\left(\times 10^{6} \mathrm{M}^{1} \mathrm{sec}^{-1}\right) \text { protein }\right)\end{array}$ & $\begin{array}{l}B_{\max } \\
(\mathrm{fmol} / \mathrm{mg}\end{array}$ \\
\hline $\begin{array}{l}\text { Mesencephalon crude } \\
\quad \text { synaptosomes }\end{array}$ & $4.9 \pm 1.1$ & $300 \pm 52$ & 3 \\
$\begin{array}{l}\text { Untreated MES23.5 } \\
\text { cAMP MES23.5 }\end{array}$ & $5.9 \pm 1.6$ & $17 \pm 1$ & 3 \\
Untreated N18TG2 & $8.2 \pm 2.5$ & $93 \pm 4$ & 3 \\
cAMP N81TG2 & $\mathrm{ND}$ & $\mathrm{ND}$ & 2 \\
& $\mathrm{ND}$ & $\mathrm{ND}$ & 2
\end{tabular}

Cell lines were maintained in log phase growth and harvested at less than $75 \%$ confluence. Cells were washed six times with PBS and stored in liquid nitrogen pending analysis. Tissue synaptosomes were treated similarly. The number of experiments, $n$, refers to complete dose curves. ND, not detected; no high-affinity sites present.

content of MES23.5 cultured under different conditions was comparable to that observed in both embryonic and adult tissue.

\section{Identification of catecholamines}

The hybrid cell line synthesized DA and its metabolites, but 5-HT, noradrenaline, and their precursors were not detected. As shown in Table 1, treatment of low-density MES23.5 cultures with dibutryl-cAMP elevated the DA content 2.5-fold from 224.9 $\mathrm{pmol} / \mathrm{mg}$ protein. The parent cell line N18TG 2 contained no catecholamines of any type, and none were detected in cultures treated with dibutryl-cAMP.

\section{Identification of voltage-gated calcium channels}

Neither the MES23.5 hybrid nor its N18TG2 parent cell line expressed appreciable levels of the L-type $\mathrm{Ca}^{2+}$ channel as measured by nifedipine-blockable PN200-100 ligand binding. Exposure to dibutryl-cAMP did not cause appearance of such receptors. However, $\mathrm{N}$-type $\mathrm{Ca}^{2+}$ channels, as detected by $\omega$-conotoxin binding, were present in the MES23.5 cell line grown under low-density basal conditions. A single high-affinity class, similar to that observed in adult mesencephalon tissue, was identified (Table 3). Saturation binding was achieved in all cases between 10 and $30 \mathrm{~min}$. Treatment of low-density MES23.5 cultures with dibutryl-cAMP resulted in a significantly increased number of $\omega$-conotoxin sites. These values suggested 1890 and 10,350 receptor sites per cell in the untreated and dibutrylcAMP-treated conditions, respectively, a 5.5-fold elevation overall.

\section{Discussion}

The MES23.5 cell line is a stable interspecies hybrid containing properties found in both the tumor parent N18TG2 and embryonic mesencephalon cells. The tumor parent is deficient in a critical enzyme in the purine-pyrimidine shunt pathway necessary to surmount the blockade of de novo DNA synthesis by aminopterin (Littlefield, 1964). Fusion of the deficient parent with normal cells, in this case rat mesencephalon cells, recovers the expression of this enzyme in the hybrids. Selection in aminopterin after somatic cell fusion therefore ensures that the derived cell lines are authentic rat $\times$ mouse hybrids.

Karyotype analysis confirms that the hybrid contains properties of both parents. As the chromosome number is less than the sum of both cell line and diploid rat cells, it is clear that extensive segregation occurred. After somatic cell fusion, the principal chromosomal loss takes place within the first few weeks and declines to a low level after the second month in culture (Weiss and Ephrussi, 1966). By this time, rat chromosomes, which condense appropriately (Rao and Johnson, 1972) with the mouse tumor mitotic apparatus, are selected and preserved. In hybrids of rat and mouse lymphoid cells, retention of mouse chromosomes is favored (Rao and Johnson, 1972). However, in this case it appears that a large variety of rat chromosomes are preserved.

The MES23.5 karyotype does not substantially differ after 4 and 12 months in continuous culture. An identical modal number of chromosomes determined at both assay points suggests that no overall deletion of chromosomes takes place over this period. The tumor parent contains 6-10 very large, highly characteristic metacentric chromosomes. The diploid rat cell contains six tiny acrocentric chromosomes that are species markers (Yoshida and Amano, 1965). The MES23.5 hybrid contains two to five large metacentric chromosomes consistent in size and shape with tumor origin and four to six of the tiny acrocentric rat marker chromosomes. A much more detailed analysis of the banding pattern of each chromosome would be needed to substantiate the initial impression that the bulk of chromosomes are derived from the rat parent.

A unique aspect of this CNS-derived cell line is its inducible synthesis of $\mathrm{D} \Lambda$, exclusive of other catccholaminc production. This is in contrast to adrenergic neuroblastomas in general, which tend to be noradrenergic or serotonergic, or even mixed cholinergic and adrenergic (Mena et al., 1989). Values for DA content have been reported of $3.92 \mathrm{pmol} / \mathrm{mg}$ for the neuroblastoma IMR-32 and $91.5 \mathrm{pmol} / \mathrm{mg}$ DA in the neuroblastoma NB69, low with respect to MES23.5. However, the two tumor lines are rich in noradrenaline, and the latter cell line also contains prominent 5-HT precursors (Mena et al., 1989). A somatic hybrid cell line derived from N18TG2 and peripheral sympathetic neurons has also yielded cells that contain TH activity and synthesizes DA, but not norepinephrine (Greene et al., 1975).

The expression of TH activity and synthesis of DA are characteristics not found in the tumor parent. A comparable value for TH content in the human neuroblastoma IMR32 of 31.8 $\mathrm{pmol} / \mathrm{hr} / \mathrm{mg}$ is reported (Gotti et al., 1987). The cell line expresses, under some conditions, levels of $\mathrm{TH}$ similar to that expected in an embryonic mesencephalic dopaminergic neuron. Remarkably, the TH content when cultured with cAMP at high density approaches levels expected in the adult mesencephalic dopaminergic neuron.

The tumor parent is a neuroblastoma and itself expresses some limited neuronal features. Excitable membranes are observed (Nelson et al., 1969), as is rubust AChE and slight amounts of authentic CAT activity. These characteristics are also present in the MES23.5 hybrid; however, the acquisition of TH and DA suggests that some neuronal characteristics of a substantia nigra neuron are present. This is not completely certain, as there are reports of the fusion of two CAT-negative tumor cell lines producing a CAT hybrid (Minna et al., 1975). These reports suggest that a silent cholinergic gene in the tumor parent has been activated by the fusion event. It is possible, but highly unlikely, that a hitherto undescribed repression sitc for TH in the N18TG2 parent is lost by segregation after the fusion event, leading to the expression of mouse $\mathrm{TH}$.

The simpler explanation is that rat $\mathrm{TH}$ is expressed along with the machinery for sequestering DA within the cell. The cyclic nucleotide dependence of TH induction lends credence to this hypothesis. Both timing and concentration dependence of $\mathrm{TH}$ 
induction exactly match in vitro observations with cultured mesencephalon. Treatment of the cell line with cAMP analogs causes an increase in $\mathrm{TH}$ activity without having any effect on the minimal CAT presumably contributed by the tumor parent. The increase in TH activity produced by cAMP treatment is commonly found in TH-containing cells such as superior cervical ganglia (Cahill and Perlman, 1987), and adrenergic cell lines such as PC12 (Roskoski and Roskoski, 1987). This incrcasc can be due either to phosphorylation changes on the TH molecule itself leading to increased catalytic activity (Cahill and Perlman, 1987), or to a variety of changes in regulation of the expression of molecules (Tank et al., 1986). The half-maximal TH stimulation is achieved at $0.1 \mathrm{mM}$ in these systems, as was observed for MES23.5. The apparent elevation suggested by the increase in immunoreactivity on electroblots suggests that the expression of TH molecules may be increased by cyclic nucleotides in MES23.5. This is an important regulatory property that would be expected in a dopaminergic neuron.

The TH content is also dependent on the culture cell density, which may be similar to the density-dependent elevation of TH reported in the pheochromocytoma PC12 (Fader and Lewis, 1990). Finally, it is very remarkable that the IH content of MES23.5 grown under high-density conditions is similar to that which may be calculated for embryonic cclls and that cyclic nucleotide treatment elevates $\mathrm{TH}$ to a level contained in adult neurons. These data suggest that not only the gene for TH expression but substantial mechanisms for its regulation are also intact in this cell line.

The presence of $\omega$-conotoxin binding sites and absence of PN200-100 sites in the hybrid cell line suggest that primarily $\mathrm{N}$-type voltage-gated $\mathrm{Ca}^{2+}$ channels are present on the cell. This is consistent with the presence of significant $\omega$-conotoxin and low levels of dihydropyridine receptors in synaptosomes prepared from adult rat ventral mesencephalon. Additionally, autoradiographic studies indicate that the substantia nigra region is rich in $\omega$-conotoxin receptors (Takemura et al., 1981) and relatively poor in dihydropyridine receptors (Quirion et al., 1985).

The hybrid cell line contains a single high-affinity class of receptor identical to that found on other cell lines, primary rat neural culture, and adult synaptosomes. Similar affinity constants have been reported for whole rat brain synaptosomes $\left(K_{1}\right.$ $\left.=5-7 \times 10^{6} \mathrm{M}^{-1} \mathrm{sec}^{-1}\right)$ and primary rat culture neurons $\left(K_{4}=\right.$ $2-4 \times 10^{6} \mathrm{M}^{\prime} \mathrm{sec}^{-1}$ ) (Marquez et al., 1988). These authors report significantly higher number of sites in adult tissue, 600 $\mathrm{fmol} / \mathrm{mg}$ compared to cultured embryonic neurons at $60 \mathrm{fmol} /$ $\mathrm{mg}$. Neuroblastomas have been assessed for $\omega$-conotoxin receptors and high-affinity sites reported, $56 \pm 9 \mathrm{fmol} / \mathrm{mg}$ for SK$\mathrm{N}-\mathrm{SH}$ and $13 \pm 1 \mathrm{fmol} / \mathrm{mg}$ for MAR5 (Usowicz et al., 1990).

The presence of cAMP-stimulated TH activity, selective DA production, and $\mathrm{N}$-type $\mathrm{Ca}^{2+}$ channel in MES23.5 strongly suggests that the rodent mesencephalic parent was a dopaminergic cell originating in the substantia nigra. Other catecholaminergic cells may have been available in the primary tissue, possibly noradrenergic-producing cells from locus ceruleus or 5-H I-producing cells from the ventral tegmentum. The specific DA production indicates that these were not likely fusion partners. The concomitant elevation of DA synthesis with $\mathrm{TH}$ elevation suggests that the adult property of efficient DA compartmentalization is also retained. Finally, the elevation of $\omega$-conotoxin receptors as a result of cyclic nucleotide treatment suggests that a unique level of regulation of neuronal properties may be present in dopaminergic neurons, and is accessible through this cell line. We conclude from these analyses that the cell line contains complex properties found in the dopaminergic cells of substantia nigra and may be a suitable model for the study of trophic factorrelated changes or other properties that may be relevant to Parkinson's disease.

\section{References}

Bernheimer H, Birkmayer W, Hornykiewicz O, Jellinger K, Seitelberger F (1973) Brain dopamine and the syndromes of Parkinson and Huntington; clinical, morphological and neurochemical observations. J Neurol Sci 20:415-455.

Bjorkland A, Lindvall O (1984) Dopamine-containing systems in the CNS. In: Handbook of chemical neuroanatomy. Classical transmitters in the CNS, Pt I, (Bjorkland A, Hokfelt T, eds), pp 55-122. New York: Elsevier.

Bostwick JR, Le W-D (1991) A tyrosine hydroxylase assay in microwells using coupled nonenzymatic decarboxylation of dopa. Anal Biochem 192:125-130.

Bottenstein JE, Sato GH (1979) Growth of a rat neuroblastoma cell line in serum-free supplemented medium. Proc Natl Acad Sci USA 76:514-517.

Burns RS, Chiueh CC, Markey SP, Ebert MH, Jacobowitz DM, Kopin IJ (1983) A primate model of Parkinsonism: selective destruction of dopaminergic neurons in the pars compacta of the substantia nigra by N-methyl-4-phenyl-1,2,3,6-tetrahydropyridine. Proc Natl Acad Sci USA 80:4546-4550.

Burns RS, LeWitt PA, Ebert MH, Parkenberg H, Kopin IJ (1985) The clinical syndrome of striatal dopamine deficiency; Parkinsonism induced by 1-methyl-4-phenyl-1,2,3,6-tetrahydropyridine (MPTP). N Engl J Med 312:1418-1421.

Cahill AL, Perlman RL (1987) Preganglionic stimulation increases the phosphorylation of tyrosine hydroxylase in the superior cervical ganglion by both cAMP-dependent and $\mathrm{Ca}^{++}$-dependent protein kinases. Biochem Biophys Acta 930:454-462.

Carvey PM, McRae A, Lint TF, Ptak LR, Lo ES, Goetz CG, Klawans HL (1991) The potential use of a dopaminergic neuron antibody and a striatal-derived neurotrophic factor as diagnostic factors in Parkinson's disease. Neurology 41:53-58.

Cashman NR (1991) Cellular and molecular biology of motor neurons: a hybrid cell strategy. IBRO Abstr 13 .

Dahlstrom A, Wigander A, Lundmark K, Gottfries C-G, Carvey PM, McRae A (1990) Investigations on auto-antibodies in Alzheimer's and Parkinson's diseases, using defined neuronal cultures. J Neural Trans 29:195-206.

Fader D, Lewis EJ (1990) Interaction of cyclic AMP and cell-cell contact in the control of tyrosine hydroxylase RNA. Mol Brain Res $8: 25-29$.

Glossmann H, Ferry DR (1985) Assay for calcium channels. In: Methods in enzymology (Birnbaummer L, O'Malley BW, eds), pp 513530. New York: Academic.

Gotti C, Sher E, Cabrini D, Bondiolotti G, Wanke E, Mancinelli E, Clementi F (1987) Cholinergic receptors, ion channels, neurotransmitter synthesis, and neurite outgrowth are independently regulated during the in vitro differentiation of a human neuroblastoma cell line Differentiation 34:144-155.

Greene IA. Shain W, Chalazonitis A, Breakfield X, Minna J, Coon HG, Nirenberg M (1975) Neuronal properties of hybrid neuroblastoma $\times$ sympathetic ganglion cells. Proc Natl Acad Sci USA 72:4923-4927.

Hammond DN, Wainer BH, Tonsgard JH, Heller A (1986) Neuronal properties of clonal hybrid cell lines derived from central cholinergic neurons. Science 234:1237-1239.

Hammond DN, Lee HJ, Tonsgard JH, Wainer BH (1990) Development and characterization of clonal cell lines derived from septal cholinergic neurons. Brain Res 512:190-200.

Konig N, Wilke MB, Lauder J (1989) Dissection of monoaminergic neuronal groups from embryonic rat brain. In: A dissection and tissue culture manual of the nervous system (Shahar, de Vellis J, Vernadakis A, Haber B, eds), pp 26-29. New York: Liss.

Laemmli EK (1970) Cleavage of structural proteins during the assembly of the head of bacteriophage T4. Nature 227:680-685.

Lechey M, Boyson SJ (1991) The biochemistry of Parkinson's discasc. In: Current neurology (Appel SG, ed), pp 233-286. Chicago: Mosby Year Book 
Lendahl U, McKay RDG (1990) The use of cell lines in neurobiology. Trends Neurosci 13:132-136.

Littlefield JW (1964) Selection of hybrids from matings of fibroblasts in vitro and their presumed recombinants. Science 145:709.

Marquez B, Martin-Moutot N, Leveque C, Courad F (1988) Characterization of the $\omega$-conotoxin-binding molecule in rat brain synaptosomes and cultured neurons. Mol Pharmacol 34:87-90.

Mena MA, de Yehenes JG, Dwork A, Ahn S, Latov N, Herberr J, Flaster E, Slonim D (1989) Biochemical properties of monoamine-rich human neuroblastoma cells. Brain Res 486:286-296.

Minna JD, Yavelow J, Coon HG (1975) Expression of phenotypes in hybrid somatic cells derived from the nervous system. Genetics 79: 373-383.

Morier E, Rips R (1982) A new technique for simultaneous assay of biogenic amines and their metabolites in unpurified mouse brain. $\mathbf{J}$ Liq Chrom 5:151-164.

Nelson P, Ruffner W, Nirenberg M (1969) Neuronal tumor cells with excitable membranes grown in vitro. Proc Natl Acad Sci USA 64: $1004-1010$.

Nirenberg M, Wilson S, Higashida H, Rotter A, Krueger K, Busis N, Ray R, Kenimer JG, Adler M (1983) Modulation of synapse formation by cyclic adenosine monophosphate. Science 222:794-799.

Oppenheim RW (1991) Cell death during development of the nervous system. Annu Rev Neurosci 14:453-501.

Penney JB, Young AB (1983) Speculations of the functional anatomy of basal ganglia disorders. Annu Rev Neurosci 6:73-94.

Purves D (1988) Body and brain, pp 35-52. Cambridge, MA: Harvard UP.

Quirion R, Lai S, Nair NP, Stratford JR, Ford RM, Oliver R (1985) Comparative autoradiographic distribution of calcium channel antagonist binding sites for 1,4-dihydropyridine and phenylalkyamine in rat, guinea pig and human brain. Prog Neuropsychopharmacol Biol Psychiatry 9:643-649.

Rand JB, Johnson CB (1981) A single-vial biphasic liquid extraction assay for choline acetyltransferase using ${ }^{3} \mathrm{H}$-choline. Anal Biochem 116:361-371.

Rao PN, Johnson RT (1972) Premature chromosome condensation: a mechanism for the elimination of chromosomes in virus-fused cells. J Cell Sci 10:495-513.

Richtand NM, Inagami T, Misano K, Kuczenski R (1985) Purification and characterization of rat striatal tyrosine hydroxylase; comparison of the activation by cyclic AMP-dependent phosphorylation and by other effectors. J Biol Chem 260:8465-8673.

Roskoski R, Roskoski LM (1987) Activation of tyrosine hydroxylase in PC12 cells by the cyclic GMP and cyclic AMP second messenger system. J Neurochem 48:236-242.

Ross RA, Biedler JL, Spengler BA, Reis DJ (1981) Neurotransmittersynthesizing enzymes in 14 human neuroblastoma cell lines. Cell Mol Biol 3:301-312.

Smith PK, Krohn RJ, Hermanson GT, Mallia AK, Gartner FH, Provenzano MD, Fujimoto EK, Goeke NM, Olson BJ, Klenk DC (1985) Measurement of protcin using bichinchonic acid. Anal Biochem 150: $76-85$.

Spencer PS, Kisby GE, Ludolph AC (1991) Slow toxins, biologic markers, and long-latency neurodegenerative disease in the western Pacific region. Neurol 41:62-66.

Stern M, Dulaney E, Gruber SB, Golbe L, Bergen M, Hurtig H, Gollomp S, Stolley P (1991) The epidemiology of Parkinson's disease; a casecontrolled study of young-onset and old-onset patients. Arch Neurol 48:903-907.

Takemura M, Kiyama H, Fukui H, Tohyama M, Wada H (1981) Distribution of the omega-conotoxin receptor in rat brain. An autoradiographic mapping. J Neurosci 32:405-416.

Tank AW, Curella P, Ham L (1986) Induction of mRNA for tyrosine hydroxylase by cyclic AMP and glucocorticoids in a rat pheochromocytoma cell line: evidence for the regulation of tyrosine hydroxylase synthesis by multiple mechanisms in cells exposed to elevated levels of both inducing agents. Mol Pharmacol 30:497-503.

Towbin H, Staehelin T, Gordon J (1979) Electrophoretic transfer of proteins from polyacrylamide gels to nitrocellulose sheets: procedure and some applications. Proc Natl Acad Sci USA 76:4350-4654.

Usowicz MM, Porzig H, Becker C, Reuter H (1990) Differential expression by nerve growth factor of two types of $\mathrm{Ca}^{2+}$ channels in rat pheochromocytoma cell lines. J Physiol (Lond) 426:95-1 16.

Weiss MC, Ephrussi B (1966) Studies of interspecific (rat $\times$ mouse) somatic hybrids. II. Lactate dehydrogenase and $\beta$-glucuronidase. Genetics 54:1111-1122.

Yoshida TH, Amano K (1965) Autosomal polymorphism in laboratory bred and wild Norway rats, Rattus norvegicus, found in Misma. Chromosoma 16:658-667. 